\title{
Effect of Chemical Sympathectomy on Myocardial Cell Division in the Newborn Rat
}

\author{
JOHN D. KUGLER, PAUL C. GILlETTE, ${ }^{(3)}$ SUSAN P. GRAHAM, ARTHUR GARSON, JR., \\ MARGARET ANN GOLDSTEIN, AND HOWARD K. THOMPSON, JR. \\ Lillie Frank Abercrombie Section of Cardiology, Department of Pediatrics and Section of Cardiovascular Sciences, \\ Department of Medicine, Baylor College of Medicine, Houston, Texas, USA
}

\begin{abstract}
Summary
Myocardial chemical sympathectomy was achieved by daily SC injection of $100 \mu \mathrm{g} / \mathrm{g}$ body weight of 6-OH-dopamine to each of 239 Holtzman newborn rat pups for the first seven days of life. Effective sympathectomy was verified by identifying a decrease in ventricular myocardial norepinephrine concentrations to $31 \% \pm 12$ S.E. of control at $\mathbf{2 0}$ days of age. Activity of DNA polymerase was used to indicate the extent of myocardial cell division.

Beginning at eight days of age, DNA polymerase activity was increased in the sympathectomized pups relative to control. The DNA polymerase activity was highest relative to control at 16 days $(235 \% \pm 31$ S.E.) and remained elevated beyond 20 days $(188 \% \pm 30$ of control). The DNA polymerase data was analyzed by covariance and was significantly greater in the 6-OH-dopamine rat pups $(P<0.001)$.
\end{abstract}

\section{Speculation}

Myocardial cell division continues for 10 to 14 days after birth in the newborn animal of several species, and the cell division then ceases by an unknown mechanism. Our findings are consistent with the hypothesis that this postnatal decrease in myocardial cell division is related to the development of cardiac sympathetic nerve ingrowth. Because nerve ingrowth was inhibited after 6-OH-dopamine and increased myocardial cell division occurred, it appears that sympathetic ingrowth indeed may play a key role in affecting myocardial cell division in the newborn animal.

The regulation of cardiac muscle cell division remains a complex problem $(1,6,10,16,20,24-26)$. Studies in the rat have shown that myocardial cell division continues after birth, but gradually decreases and reaches the adult stage of no further division by 3 wk of age $(1,20,25,26)$. Investigators also have found that if the cardiovascular system of the newborn animal is stressed, e.g., by altered nutrition (16) or anemia (24), increased myocardial muscle cell hyperplasia may occur. However, in the adult animal, myocardial muscle cell hypertrophy and connective tissue hyperplasia occur, but muscle cell hyperplasia has not been demonstrated (10, 24, 29).

Inasmuch as it has been shown in several animal species that cardiac sympathetic nerve ingrowth is incomplete at birth (11-13, 22 ), the hypothesis has been proposed that the postnatal decrease in myocardial cell division is associated with the development of the cardiac adrenergic nervous system $(6,15)$. The derivation of the hypothesis was based on the results of animal investigations of cardiac sympathetic nerve ingrowth combined with those from separate studies of the effects of sympathomimetic drugs on myocardial cell division. To our knowledge, no investigators have evaluated both the sympathetic nervous system and myocardial cell division in the same study.

It was the purpose of this study to determine the effect of chemical sympathectomy on myocardial cell division in the newborn rat.

\section{MATERIALS AND METHODS}

Chemical sympathectomy was accomplished by the administration of 6-hydroxydopamine (6-OHD) to newborn rat pups. The activity of DNA polymerase in the ventricular homogenate was used to indicate the extent of ventricular myocardial cell division.

\section{CHEMICAL SYMPATHECTOMY TECHNIQUE}

A total of 481 Holtzman (Madison, WI) newborn rat pups were used in the study. There were 242 control pups and $2396-\mathrm{OHD}$ pups. A group of four or six pregnant rats was received every other wk. Each group of litters had nearly the same birth date (within $24 \mathrm{hr}$ ), and the sizes of the litters were equalized by transferring pups from large to small litters. The litters from onehalf of each group were used for control, and the other one-half was used for the daily SC administration of 6-OHD (Sigma Chemical Co., St. Louis, MO). For example, if one group consisted of four litters, each pup from two litters was given an injection of $0.1 \mathrm{ml}$ of $0.001 \mathrm{~N} \mathrm{NaCl}$, and each pup from the other two litters was given an injection at the same time with $0.1 \mathrm{ml}$ of $6-\mathrm{OHD}$ $(100 \mu \mathrm{g} / \mathrm{g}$ body weight of 6-OHD dissolved in $0.001 \mathrm{~N} \mathrm{NaCl})$. Because of the rapid deactivation of dissolved 6-OHD, it was administered to the pups within $5 \mathrm{~min}$ after dissolving. Injection was made into the loose skin of the nape within $24 \mathrm{hr}$ after birth and repeated once daily for 7 days. These techniques were repeated for each of 22 groups of litters.

In both the control and experimental groups of rats, DNA polymerase and ventricular norepinephrine assays were carried out at 4-day intervals beginning at 4 days of age. Because of the small size of the pups and thus small ventricular homogenates despite pooling, norepinephrine and DNA polymerase assays could not be determined in the same animals. Selection of pups was random for DNA polymerase assay (144 control and 138 6OHD) and for the norepinephrine assay (98 control and 1016 OHD).

\section{VENTRICULAR NOREPINEPHRINE ASSAY}

Norepinephrine concentration in ventricular muscle was measured by a modification of the spectrophotofluorometric procedure of Chang (3). The homogenates from the control and 6-OHDtreated rats were assayed separately, but simultaneously so that results for each set of assays were expressed as a percentage of control. From 1 to 6 rats, trimmed ventricles (carefully excluding the atria, great arteries, and other nonventricular tissue) were pooled to obtained 150 to $500 \mathrm{mg}$ of tissue. The ventricles were rinsed in cold $0.9 \% \mathrm{NaCl}$, minced, and homogenized in 10 volumes cold acidified $n$-butyl alcohol $(0.85 \mathrm{ml}$ concentrated $\mathrm{HCl}$ per liter butanol). The homogenate was centrifuged $10 \mathrm{~min}$ at $800 \times \mathrm{g}$, 
and the supernatant was placed in screw-cap tubes with $5 \mathrm{ml}$ water and 5 to $8 \mathrm{ml} n$-heptane. After shaking $5 \mathrm{~min}$, the tubes were centrifuged $5 \mathrm{~min}$ in a tabletop centrifuge. The $5 \mathrm{ml}$ aqueous phase was transferred to a clean tube containing $0.2 \mathrm{~g}$ alumina (which had been treated according to Crout et al. (7), and $1 \mathrm{ml}$ of $2 \mathrm{M}$ sodium acetate was added. After the tubes were shaken and centrifuged, the supernatant was removed by aspiration, and $3 \mathrm{ml}$ of $0.1 \mathrm{M}$ acetic acid were added to the alumina, followed by shaking and centrifugation.

To $1 \mathrm{ml}$ of supernatant was added $0.2 \mathrm{ml}$ of EDTA reagent (37.2 g ethylenediaminetetraacetic acid per liter $1 \mathrm{M}$ sodium acetate, $\mathrm{pH} 6.8$ with $\mathrm{NaOH})$. The $\mathrm{pH}$ was adjusted to 6.5 . Then, $0.1 \mathrm{ml}$ of $9.0 \mathrm{~N}$ iodine $(0.125 \mathrm{~g} / 10 \mathrm{ml}$ absolute ethanol $)$ was added, and after $2 \mathrm{~min}$, the oxidation was stopped by $0.2 \mathrm{ml}$ alkaline sulfite $(2.5 \mathrm{~g}$ anhydrous sodium sulfite dissolved in $10 \mathrm{ml}$ water; $1 \mathrm{ml}$ of sodium sulfite diluted with $9 \mathrm{ml} 5 \mathrm{~N} \mathrm{NaOH}$ the day of use). After $2 \mathrm{~min}, 0.2 \mathrm{ml}$ of $5 \mathrm{~N}$ acetic acid was added, adjusting the $\mathrm{pH}$ to 5.4 .

Norepinephrine concentrations were determined by reading the fluorescence after $60 \mathrm{~min}$ (activation, $385 \mathrm{~nm}$; emission, $485 \mathrm{~nm}$ ). Tissue blanks, reagent blanks, and the norepinephrine standard were carried through the procedure along with the experimental samples.

\section{DNA POLYMERASE ASSAY}

The cytoplasmic DNA polymerase (6 to $8 \mathrm{~S}$ soluble) activity was assayed according to the method of Doyle et al. (9), and Claycomb (5). Immediately after the pups were decapitated, the ventricles were rapidly trimmed (carefully excluding the atria, great arteries, and other nonventricular tissue), minced, and washed in ice-cold $0.9 \% \mathrm{NaCl}$ solution. Ventricles were pooled to obtained 150 to 500 $\mathrm{mg}$ of tissue (one to six rats, depending on size and age). In a given group, ventricular homogenates from control pups were kept separate from those from age-matched 6-OHD pups but assayed simultaneously on a given day. Denatured calf thymus DNA (Sigma Chemical Co.) was used as the primer template.

Protein content of the supernatant was estimated by the procedure of Lowry et al. (23). Results of the activity of the DNA polymerase (in triplicate for each of the control and 6-OHD determinations) were corrected for zero time controls, averaged, and expressed as cpm/mg protein.

\section{AUTORADIOGRAPHY}

To confirm that changes in DNA polymerase activity reflected cardiac muscle cell division, light microscopic autoradiography was performed on six pups (one 6-OHD and one control at 2, 10 , and 21 days of age). Four hr after SC injection of $50 \mu \mathrm{Ci}$ of $\left[{ }^{3} \mathrm{H}\right]$ thymidine per $\mathrm{g}$ body weight, the 2 - and 10 -day-old rats were sacrificed by decapitation. Four hr after the first injection, the 21day-old rats were given a second equal injection of $\left[{ }^{3} \mathrm{H}\right]$ thymidine and sacrificed $2 \mathrm{hr}$ later. Immediately after decapitation, the heart was exposed by thoracotomy and given an injection of $4 \%$ paraformaldehyde:5\% glutaraldehyde in phosphate buffer $(\mathrm{pH} 7.5)$ according to Karnovsky (19). Strips of left ventricle and papillary muscle were pinned in the same solution for 45 to $60 \mathrm{~min}$. The tissue was minced into one-mm cubes and placed in fresh fixative for $90 \mathrm{~min}$, rinsed $1 \mathrm{hr}$ in buffer, postfixed $90 \mathrm{~min}$ in $1 \%$ osmium tetroxide in phosphate buffer ( $\mathrm{pH} 7.5)$, dehydrated in ethanol, and oriented and embedded in Epon in flat silastic molds. Half- $\mu \mathrm{m}$ sections were cut with a glass knife and coated with Ilford L4 Emulsion [after the method of Caro and van Tubergen (2)]. Slides were refrigerated in a light-proof box for 5 to $10 \mathrm{wk}$. Sections were developed in Kodak D 19 for $4 \mathrm{~min}$ at $20^{\circ} \mathrm{C}$, rinsed in water, fixed for $4 \mathrm{~min}$ in filtered rapid fix, washed three times for $10 \mathrm{~min}$, strained with $1 \%$ methylene blue and $1 \%$ azure II in $1 \%$ sodium borate, and viewed by brightfield microscopy.

The number of radioactively labeled nuclei for the cardiac muscle cells were compared to the number of labeled nuclei for the cardiac nonmuscle cells. Two blocks of tissue were selected at random for each pup and coded. Five to ten sections from each block were counted to give the average number of labeled cardiac muscle cells and the average number of labeled cardiac nonmuscle cells. All counts were taken from tissue sections in which the muscle fibers were oriented longitudinally, and the counts were taken within precise, consecutive microscopic fields.

\section{ANALYSIS OF DATA AND STATISTICAL METHODS}

The date were grouped according to age (see "Results"). Inasmuch as the assays were done on different days over several wk involving different litters and probably slightly different wk-to-wk laboratory conditions, the data in each assay were averaged within each age interval.

Statistical analysis of the data was performed using a covariance analysis (27). The dependent variable of interest in this study was the $\mathrm{cpm} / \mathrm{mg}$ of protein. Covariance analysis was performed after logarithmic transformation of this quantity to compensate for a markedly asymmetrical distribution with skewness to the right. A second-degree polynomial regression model was applied such that the natural $\log$ of the $\mathrm{cpm} / \mathrm{mg}$ of protein was assumed to be dependent on linear and quadratic functions of time following birth. To adjust for possible variability among litter groups, membership in either a treatment or control category was also included in the model as a covariate. This analytic approach was used to compare the radioactivity per mg of protein in the control and 6OHD animals after adjustment for time following birth and possible variability among litter groups.

In an attempt to decrease some of the uncontrolled variability of the $\mathrm{cpm} / \mathrm{mg}$ of protein, this variable also was examined in the 6-OHD animals as a percentage of the corresponding variable for control animals studied at the same time and under identical circumstances.

\section{RESULTS}

\section{VERIFICATION OF SYMPATHECTOMY}

The ventricular norepinephrine concentrations in the 6-OHD rats were expressed as fluorescence per $\mathrm{mg}$ of heart weight and then as percentage of control. As age of the rats increased, a decrease in the ventricular norepinephrine levels relative to control occurred in the 6-OHD rats (Fig. 1). At 8 days of age, the mean value of ventricular norepinephrine in the 6-OHD rats was $44.9 \%$ \pm 7.6 (mean \pm S.E.) of control. The nadir of ventricular norepinephrine $(30.9 \% \pm 11.7)$ relative to control was at 20 days of age.

\section{DNA POLYMERASE ACTIVITY}

The DNA polymerase activity of the 6-OHD-treated rats was expressed as percentage of control. The mean value relative to

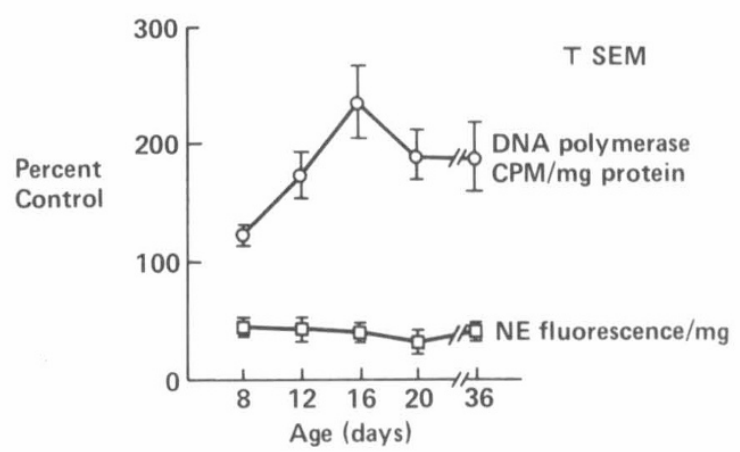

Fig. 1. Mean DNA polymerase activity and mean norepinephrine concentration in the 6-OHD rats are expressed as a percentage of control and plotted versus age in days. The DNA polymerase activity relative to control is increased from 8 to 36 days, reaching the highest value $(235 \% \pm 31)$ at 16 days of age and remaining increased beyond 20 days of age $(188 \% \pm 30$ of control). Verification of sympathectomy in the 6-OHD rats is shown by the decreased norepinephrine concentrations relative to control with the lowest mean value $(31 \% \pm 12$ of control) found at 20 days of age. $N E$, norepinephrine. 


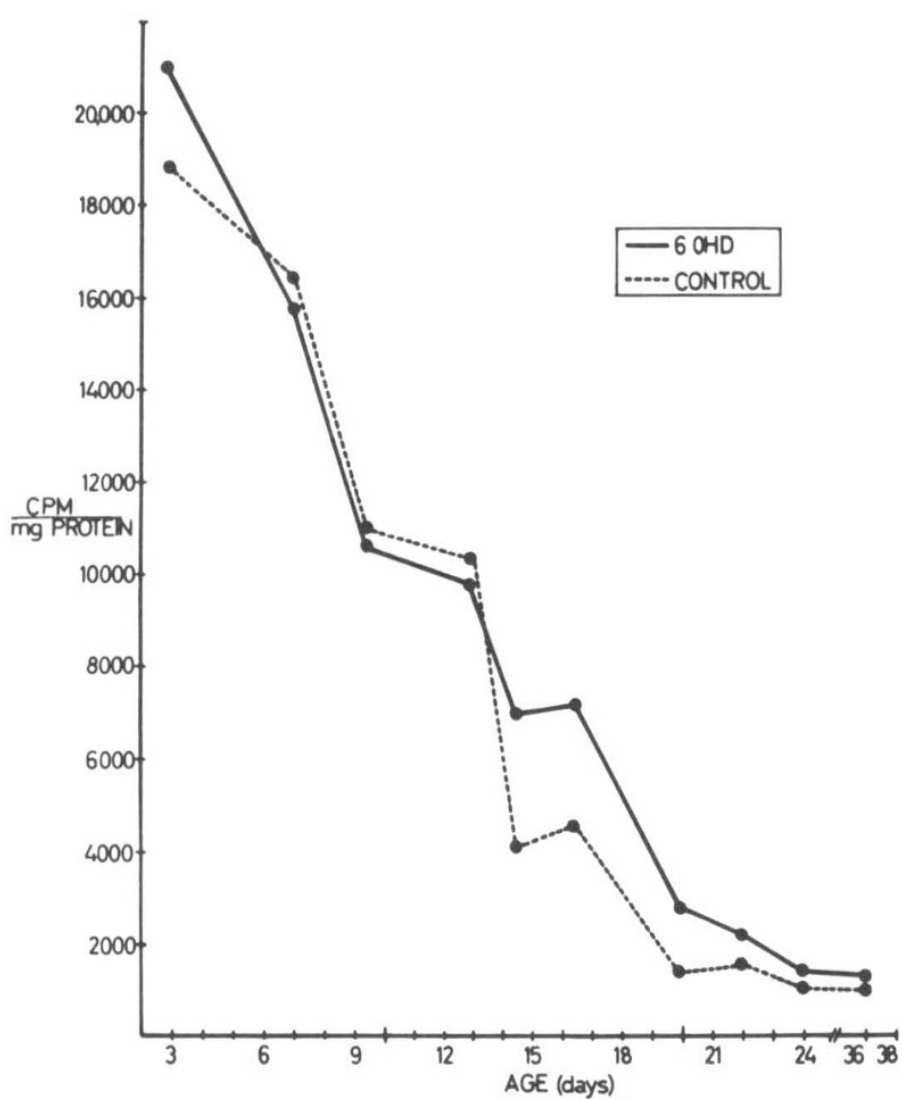

Fig. 2. Median values for DNA polymerase activity for 6-OHD rats and control rats are plotted vesus age in days. The DNA polymerase activity decreased in both 6-OHD and control rats; however, beyond 13 days of age, the decrease is delayed in the sympathectomized rats.

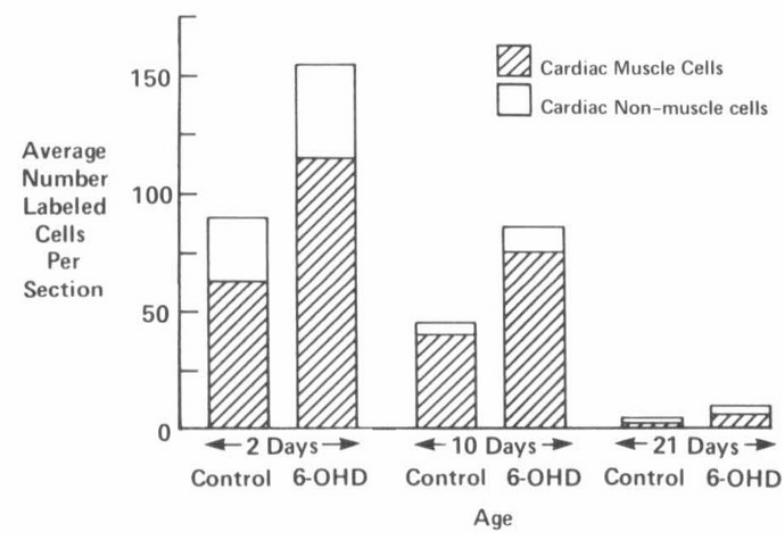

Fig. 3. Results of autoradiography with the average number of labeled cells per section of tissue (labeled cardiac muscle cells and labeled cardiac nonmuscle cells) for control and 6-OHD rats at 2, 10, and 21 days of age. The labeled cardiac muscle cells comprised almost all of the total labeled cells in each control and 6-OHD rat and at each age.

control was $123 \% \pm 8.8$ at 8 days and $235.1 \% \pm 31.0$ at 16 days (Fig. 1). After 16 days, the DNA polymerase activity decreased compared to control, but remained greater than control after 20 days $(188.0 \% \pm 29.8)$.

The median value of absolute DNA polymerase activity is plotted with the respective ages in Figure 2. Although the DNA polymerase activity decreased in both groups, beyond 13 days of age the decrease in the values for the 6-OHD rats was delayed. Because the two curves in Figure 2 were obtained from data of different animals, it was not strictly appropriate to compare the control and treated animals using paired statistical comparisons, even though some rats were studied on the same day and in the same manner and might be considered to be controls for the 6OHD-treated rats studied under identical circumstances. Therefore, no attempt is made on the basis of this type of data presentation to provide a statistical comparison of the two curves in Figure 2 .

When the absolute data were analyzed using analysis of covariance, the DNA polymerase activity from the 6-OHD rats was significantly higher than the control. The adjusted $\log _{e}$ DNA polymerase activity in the 6-OHD-sympathectomized rats was $8.21 \pm 0.58$ (mean \pm S.D.) compared to $7.8 \pm 0.59(P<0.001)$.

\section{AUTORADIOGRAPHY}

The results of the autoradiography showed the confirmatory finding that DNA polymerase activity reflected cardiac muscle cell division. At each age and in each control and each 6-OHD rat, the labeled (thus actively dividing) cardiac muscle cells comprised almost all of the total labeled cells (Fig. 3).

\section{DISCUSSION}

In the 6-OHD rats, the temporal occurrence of the decreased presence of ventricular sympathetic innervation (decreased norepinephrine levels) with the increased DNA polymerase activity relative to control supports the hypothesis that myocardial cell division and sympathetic nerve ingrowth are linked. DNA polymerase has been found to accurately reflect myocardial cell proliferative activity $(6,9,10)$. Cardiac DNA polymerase activity not only has been characterized (5), but this enzyme as well as another myocardial replicative enzyme, thymidine kinase, have correlated with $\left[{ }^{3} \mathrm{H}\right]$ thymidine incorporation as an indicator of ventricular mitotic activity $(5,14)$. Moreover, we have used autoradiography in this study to verify that DNA polymerase activity reflects cardiac muscle cell division in both the control and 6-OHDtreated rats.

We used chemical sympathectomy by 6-OH-dopamine in this study to determine the effect of ablating the sympathetic nervous system because 6-OHD has been shown clearly to destroy adrenergic neurons of newborn animals (21). In some animal studies, the ventricular norepinephrine levels has decreased to $5 \%$ of control when the agent was administered IV $(8,17,18)$. Histochemical fluorescent techniques have verified that ventricular norepinephrine levels directly correlate with the extent of myocardial sympathetic nerves both in the nonsympathectomized animal and in the 6-OHD sympathectomized animal $(8,12)$. Our finding that the 6-OHD rats had ventricular norepinephrine levels of 30 to $45 \%$ of control after SC injection for the first 7 days of life is comparable to the work of deChamplain (8) who found that most of the sympathetic neurons were destroyed. That the norepinephrine levels were not as low as those in some 6-OHD rats studied (17) can be explained partly by the finding of deChamplain (8) and Clark et al. (4) that regeneration of the adrenergic nerves may occur in either adult or young rats who have been administered 6-OHD. In addition, because studies have shown that the catecholamine concentrations in the adrenal gland are not affected by 6-OHD-induced chemical sympathectomy (4, 21 ), it is likely that some of the norepinephrine in 6-OHD rat ventricles is blood borne and of adrenal origin.

The studies of Gillette and Claycomb (15) and Claycomb (6) support the association of cardiac sympathetic nerve ingrowth with decreasing myocardial cell division. Although the sympathetic nervous system per se was not manipulated in these studies, isoproterenol alone and in combination with theophylline was administered to rats. Using thymidine kinase activity and $\left[{ }^{3} \mathrm{H}\right]$ thymidine incorporation as indices of DNA synthesis, these investigators showed that isoproterenol and theophylline caused a dosedependent decrease in thymidine kinase activity and $\left[{ }^{3} \mathrm{H}\right]$ thymidine incorporation in the newborn rat heart. The decrease occurred at an earlier age in the treated rats than in the controls, who normally showed a cessation of DNA synthesis activity at 15 to 21 days of age. These observations and the findings of other 
investigators that there is a normal postnatal increase in ventricular norepinephrine (i.e., ingrowth of adrenergic nerves) (11-13) have led to the hypothesis that cardiac sympathetic nerve ingrowth may play a role in the cessation of myocardial cell division. Inasmuch as inhibition of sympathetic nerve growth (chemical sympathectomy) resulted in increased indices of myocardial cell division in our study, the conclusion is further supported that adrenergic nerve ingrowth and cessation of myocardial cell division are associated.

Changes in beta-receptors probably are not related to cessation of myocyte division. Friedman (11), using infusion of norepinephrine and isoproterenol in sheep ventricular muscle strips together with cardiac sympathetic nerve studies in rabbits, lambs, and swine (which showed immature adrenergic nerve ingrowth at birth in each species) concluded that beta-receptors were intact in neonatal animals. The fact that the adrenergic nerves and not beta-receptors were destroyed by chemical sympathectomy probably explains in part why animals are not affected more severely by the sympathectomy. In addition, because the adrenal gland is not affected by 6-OHD, compensatory increases in their production of catecholamines could help maintain cardiac function. If adrenalectomy was accomplished along with sympathectomy, thus making sympathectomy more complete, myocardial cell division might continue longer.

In man, correlation of our findings are speculative because studies of sympathetic nerve ingrowth and cessation of myocardial cell division in humans have not been done to our knowledge. It is tempting to relate cardiac defects such as hypertrophic obstructive cardiomyopathy to abnormal development or activity of fetal/ newborn cardiac sympathetic growth. Witzhe and Kaye (28) induced hypertrophic cardiomyopathy by administering nerve growth factor to newborn puppies. Perhaps the increased adrenergic nerve growth caused a premature decrease in myocardial muscle cell division, yet an intense myocardial cell growth without hyperplasia ensued, leading to myofibrillar disarray and the other pathologic findings found in the puppies. Further speculation involves the fetal cardiac effects from maternal use of either sympathomimetic or antisympathomimetic drugs.

The control of myocardial cell division is an important but unsolved problem. An understanding of this problem would have implications in many aspects of cardiovascular science. The early stages of postnatal cardiac development offer an excellent opportunity to study the control of myocardial cell division. Although this investigation showed a relationship between the initial ingrowth of the sympathetic nervous system and the cessation of myocardial cell division, it is likely that there are additional factors involved in the control of myocardial cell division.

\section{REFERENCES AND NOTES}

1. Akhabadze, L. V.: Radioautographic and cytometric analysis of myocyte growth and myocardial regeneration in rats. Ontogenez, 5: 163 (1974).

2. Caro, L. G., and van Tubergen, R. P.: High resolution autoradiography. J. Cell Biol., 15: 173 (1962).

3. Chang, C. C.: A sensitive method for spectrophotofluorometric assay for catecholamines. Int. J. Neuropharmacol., 3: 643 (1964).

4. Clark, D. W. J., Laverty, R., and Phelan, E. L.: Long-lasting peripheral and central effects of 6-hydroxydopamine in rats. Br. J. Pharmacol., 44: 233 (1972).

5. Claycomb, W. C.: Biochemical aspects of cardiac muscle differentiation. Deoxyribonucleic acid synthesis and nuclear and cytoplasmic deoxyribonucleic acid polymerase activity. J. Biol. Chem., 250: 3229 (1975).

6. Claycomb, W. C.: Biochemical aspects of cardiac muscle differentiation. Possible control of deoxyribonucleic acid synthesis and cell differentiation by adrenergic innervation and cyclic adenosine 3':5'-monophosphate. J. Biol. Chem., 251: 6082 (1976).
7. Crout, J. R., Creveling, C. R., and Udenfreind, S.: Norepinephrine metabolism in rat brain and heart. J. Pharmacol. Exp. Ther., 132: 269 (1961).

8. deChamplain, J.: Degeneration and regrowth of adrenergic nerve fibers in the rat peripheral tissues after 6-hydroxydopamine. Can. J. Physiol. Pharmacol., 49. 345 (1975).

9. Doyle, C. M., Zak, R., and Rischman, D. A.: The correlation of DNA synthesis and DNA-polymerase activity in the developing chick heart. Dev. Biol., 37: 133 (1974).

10. Fischman, D. A., Doyle, C. M., and Zak, R.: DNA synthesis in chick cardiac muscle: comparative observations of in vivo and in vitro growth. In: $M$. Lieberman, T. Saro: Perspectives in Cardiovascular Research, Developmental and Physiologic Correlates of Cardiac Muscle, p. 67 (Raven Press, New York, 1976).

11. Friedman, W. F.: The intrinsic physiologic properties of the developing heart. In: W. F. Friedman, M. Lesch, E. H. Sonneblick: Neonatal Heart Disease. p. 21 (Grune \& Stratton, New York, 1972).

12. Friedman, W. F., Pool, P. E., Jacobowitz, D., Seagren, S., and Braunwald, E.: Sympathetic innervation of the developing rabbit heart. Circ. Res., 13: 25 (1968).

13. Gauthier, P., Nadeau, R. A., and deChamplain, J.: The development of sympathetic innervation and the functional state of the cardiovascular system in newborn dogs. Can. J. Physiol. Pharmacol., 53: 763 (1975).

14. Gillette, P. C., and Claycomb, W. C.: Thymidine kinase activity in cardiac muscle during embryonic and postnatal development. Biochem. J., 142: 685 (1974).

15. Gillette, P. C., and Claycomb, W. C.: Possible role of sympathetic innervation on control of cardiac muscle thymidine kinase. Pediatr. Res. (abstract), 9: 276 (1975).

16. Hollenberg, M., Honbo, N., and Samorodin, A. J.: Cardiac cellular responses to altered nutrition in the neonatal rat. Am. J. Physiol./H. Circ. Physiol., 2: H356 (1977).

17. Jaim-Etcheverry, G., and Zieher, L. M.: Permanent depletion of peripheral norepinephrine in rats treated at birth with 6-hydroxydopamine. Eur. J. Pharmacol., 13: 272 (1971).

18. Jonsson, G., and Sachs, C.: Effects of 6-hydroxydopamine on the uptake and storage of noradrenaline in sympathetic adrenergic neurons. Eur. J. Pharmacol., 9: 141 (1970).

19. Karnovsky, M. J.: A formaldehyde-glutaraldehyde fixative of high osmolality for use in electron microscopy. J. Cell Biol., 27: 137A (1965).

20. Klinge, O., and Stocker, E.: Die DNA-Synthase in Rattenhergen als Funktion des Lebensalters. Autoradiographicsche Untersuchungen mit ${ }^{3} \mathrm{H}$-Thymidin. Experientia, 24: 167 (1968).

21. Kostrzew, R. M., and Jacobowitz, D. M.: Pharmacological action of 6-hydroxydopamine. Pharmacol. Rev., 26: 199 (1974).

22. Lebowitz, E. A., Novick, J. S., and Rudolph, A. M.: Development of myocardial sympathetic innervation in the fetal lamb. Pediatr. Res., 6: 887 (1972).

23. Lowry, O. H., Resenbrough, N. J., Farr, A. L., and Randall, R. J.: Protein measurement with the folin phenol reagent. J. Biol. Chem., 193: 265 (1951).

24. Neffgen, J. F., and Korecky, B.: Cellular hyperplasia and hypertrophy in cardiomegalies induced by anemia in young and adult rats. Circ. Res., 30: 104 (1972).

25. Rumyantsev, P. P.: DNA synthesis and nuclear division in embryonal and postnatal histogenesis of myocardium (autoradiographic study). Fed. Proc. (Trans. Suppl.), 24: T899 (1965).

26. Rumyantsev, P. P.: A morphological and autoradiographical study of the peculiarities of differentiation rate, DNA synthesis and nuclear division in the embryonal and postnatal histogenesis of cardiac muscles of white rats. Folia Histochem. Cytochem., 1: 463 (1973).

27. Searle, S. R.: Linear Models. p. 292 (John Wiley \& Sons, Inc., New York, 1971).

28. Witze, D. J., and Kaye, M. P.: Hypertrophic cardiomyopathy induced by administration of nerve growth factor. Circulation Suppl., 2: II-88 (1976).

29. Zak, R.: Development and proliferative capacity of cardiac muscle cells. Circ. Res., 34/35: II-17 (1974).

30. Presented in part at the Scientific Session of the Section on Cardiology, American Academy of Pediatrics, October 21, 1978.

31. The present address of Dr. John D. Kugler is: Pediatric Cardiology, University of Nebraska College of Medicine, 42nd and Dewey, Omaha, NB 68105 (USA).

32. The authors thank David Murphy for his technical assistance and Sandra Haley and Mary Fry for typing the manuscript.

33. Requests for reprints should be addressed to: Paul C. Gillette, M.D., Section of Pediatric Cardiology, Texas Children's Hospital, 6621 Fannin Street, Houston, Texas 77030

34. This research was supported in part by the National Research and Demonstration Center, Grant HL 07190, by Grant HL-5756 from the National Institutes of Health, United States Public Health Service, and by a grant from the J. S. Abercrombie Foundation.

35. Received for publication May 14, 1979.

36. Accepted for publication September 26, 1979. 